\title{
Commentary: Lactobacilli Dominance and Vaginal pH: Why Is the Human Vaginal Microbiome Unique?
}

\author{
Virginia Fuochi ${ }^{1+}$, Giovanni Li Volti ${ }^{2+}$ and Pio Maria Furneri ${ }^{1 *}$ \\ ${ }^{1}$ Microbiology Section, Department of Biomedical and Biotechnological Sciences, University of Catania, Catania, Italy, \\ ${ }^{2}$ Medical Biochemistry Section, Department of Biomedical and Biotechnological Sciences, Biological Tower, University of \\ Catania, Catania, Italy
}

Keywords: Lactobacillus spp., vaginal microbiome, pH, estrogens, lactic Acid

\section{A commentary on}

Lactobacilli Dominance and Vaginal pH: Why Is the Human Vaginal Microbiome Unique? by Miller, E. A., Beasley, D. E., Dunn, R. R., and Archie, E. A. (2016). Front. Microbiol. 7:1936.

OPEN ACCESS

Edited by: Omry Koren,

Bar-Ilan University, Israel

Reviewed by:

Rebeca Martín,

INRA Centre Jouy-en-Josas, France

Suleyman Yildirim,

School of International Medicine,

Istanbul Medipol University, Turkey

*Correspondence:

Pio Maria Furneri

furneri@unict.it

${ }^{\dagger}$ These authors have contributed equally to this work.

Specialty section:

This article was submitted to

Microbial Symbioses,

a section of the journal

Frontiers in Microbiology

Received: 03 July 2017 Accepted: 06 September 2017 Published: 25 September 2017

Citation:

Fuochi V, Li Volti G and Furneri PM (2017) Commentary: Lactobacilli

Dominance and Vaginal pH: Why Is the Human Vaginal Microbiome Unique?. Front. Microbiol. 8:1815. doi: 10.3389/fmicb.2017.01815 doi: 10.3389/fmicb.2016.01936

Vaginal microbiota is involved in the homeostasis of mammal female's physiological conditions (Jašarević et al., 2015), avoiding vaginal infections such as aerobic vaginitis, bacterial vaginosis, and candidiasis (Vitali et al., 2007; Tempera and Furneri, 2010; Heczko et al., 2015). To this regard, the genus Lactobacillus plays a major role in women vagina, exerting its beneficial functions by lactic acid and bacteriocins production (Fuochi et al., 2017; Tachedjian et al., 2017). Furthermore, the very low $\mathrm{pH}$ (4.5-6.0) of the genital tract should be taken into due account in protection of the host (Wylie and Henderson, 1969). Miller et al. have analyzed and put together possible hypotheses (Figure 1) in order to explain the important correlation between Lactobacilli dominance and vaginal $\mathrm{pH}$ in human species. They further elaborated their own theory as a possible explanation of that peculiarity. In particular, the authors suggested that the high level of glycogen, present in the human females' vagina but not in other mammal species, could be an energy source for Lactobacillus growth. Such presence should be due to the human diet particularly rich in starch. Although, we do share Miller's exhaustive hypotheses and conclusions, we would like to point out additional aspects that have to be taken into due account. On the one hand, vaginal epithelium is rich in glycogen as well as cervico-vaginal mucus is rich in mucins and glycoproteins and therefore there are very high levels of nutrients allowing colonization and dominance of lactobacilli (Martín Rosique et al., 2008; Mirmonsef et al., 2014; Nunn and Forney, 2016). On the other hand, high glycogen concentrations are dependent on the high levels of estrogen (Mirmonsef et al., 2016). Moreover, Gorodeski et al. (2005) provided a further explanation for vaginal pH: vaginal cells seem to contribute to luminal acidity through an active and estrogen-dependent proton secretion throughout the woman's life.

Furthermore, women's life is characterized by continuous physiological changes, from their birth through the reproductive age to menopause, and during all these phases the vaginal microbiota and vaginal epithelium radically change (Paavonen, 1983). The fertile age is characterized by monthly ovulation and therefore high estrogenic levels which, also thanks to the action of proton pumps (Aldunate et al., 2015; Mirmonsef et al., 2016), lead the vaginal lumen to be particularly acid. The combined effect of the presence of glycogen and low $\mathrm{pH}$ render provide the best conditions for the growth of Lactobacillus. 


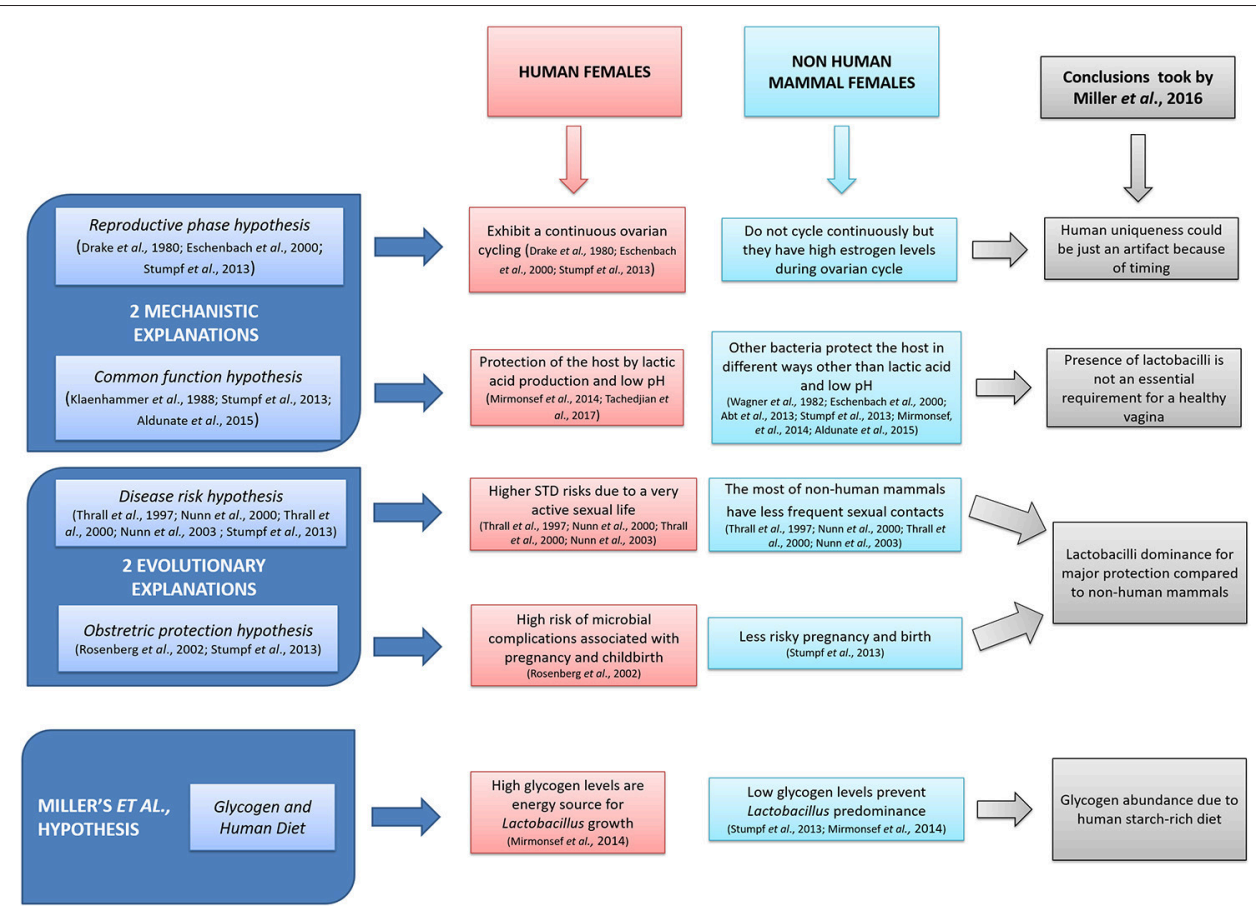

FIGURE 1 | Miller et al. (2016): a schematic representation.

When the woman reaches the menopause this pattern changes significantly because estrogens are no longer present and the glycogen level decreases leading to a significant modification of vaginal microbiota characterized in particular by a decrease in the amount of lactobacilli (Roccasalva et al., 2002; Hickey et al., 2012; Nunn and Forney, 2016; Shen et al., 2016). The importance of estrogens is further substantiated by the evidence that restoring estrogen levels results in improved trophic conditions of the vaginal epithelium restoring all the benefits arising from such condition (Paavonen, 1983; Roccasalva et al., 2002; Gorodeski et al., 2005; Lien et al., 2009; Hickey et al., 2012; Nunn and Forney, 2016; Shen et al., 2016).

As far as the diet theory is concerned, different vaginal ecotypes should exist according to the different types of diets in the same way as different habits and practices (Lien et al., 2009; Hickey et al., 2012), and this would be accentuated in cases of intolerance or allergies. In particular, in patients with celiac disease, women might have a very different vaginal microbiota,

\section{REFERENCES}

Abt, M. C., and Artis, D. (2013). The dynamic influence of commensal bacteria on the immune response to pathogens. Curr. Opin. Microbiol. 16, 4-9. doi: 10.1016/J.Mib.2012.12.002

Aldunate, M., Srbinovski, D., Hearps, A. C., Latham, C. F., Ramsland, P. A., Gugasyan, R., et al. (2015). Antimicrobial and immunemodulatory effects of lactic acid and short chain fatty acids produced by vaginal microbiota associated with eubiosis and bacterial vaginosis. Front. Physiol. 6:164. doi: 10.3389/fphys.2015.00164 and therefore it would be very interesting to carry out a study to confirm a closer relationship between diets and vaginal microbiota.

In conclusion, we believe that Miller's observations are of great interest for the field, but in our opinion the explanation is more related to the mechanistic theories (reproductive phase hypothesis and common function hypothesis) than it is to the others. Nevertheless, we believe that uniqueness of human vaginal microbiome is due to all five theories (including Miller's hypothesis), intersecting each other, and from which it is impossible to extrapolate one single mechanistic theory.

\section{AUTHOR CONTRIBUTIONS}

All authors listed have made a substantial, direct and intellectual contribution to the work, and approved it for publication. 
Gorodeski, G. I., Hopfer, U., Liu, C. C., and Margles, E. (2005). Estrogen acidifies vaginal $\mathrm{pH}$ by up-regulation of proton secretion via the apical membrane of vaginal-ectocervical epithelial cells. Endocrinology 146, 816-824. doi: 10.1210/en.2004-1153

Heczko, P. B., Tomusiak, A., Adamski, P., Jakimiuk, A. J., Stefański, G., Mikołajczyk-Cichońska, A., et al. (2015). Supplementation of standard antibiotic therapy with oral probiotics for bacterial vaginosis and aerobic vaginitis: a randomised, double-blind, placebo-controlled trial. BMC Women's Health 15:115. doi: 10.1186/s12905-015-0246-6

Hickey, R. J., Zhou, X., Pierson, J. D., Ravel, J., and Forney, L. J. (2012). Understanding vaginal microbiome complexity from an ecological perspective. Transl. Res. 160, 267-282. doi: 10.1016/j.trsl.2012. 02.008

Jašarević, E., Howerton, C. L., Howard, C. D., and Bale, T. L. (2015). Alterations in the vaginal microbiome by maternal stress are associated with metabolic reprogramming of the offspring gut and brain. Endocrinology 156, 3265-3276. doi: 10.1210/en.2015-1177

Klaenhammer, T. R. (1988). Bacteriocins of lactic acid bacteria. Biochimie 70, 337-349. doi: 10.1016/0300-9084(88)90206-4

Lien, T. F., Hsu, Y. L., Lo, D. Y., and Chiou, R. Y. (2009). Supplementary health benefits of soy aglycons of isoflavone by improvement of serum biochemical attributes, enhancement of liver antioxidative capacities and protection of vaginal epithelium of ovariectomized rats. Nutr. Metab. 6:15. doi: 10.1186/1743-7075-6-15

Martín Rosique, R., Soberón Maltos, N. E., Vaneechoutte, M., Flórez García, A. B., Vázquez Valdés, F., and Suárez Fernández, J. E. (2008). Characterization of indigenous vaginal lactobacilli from healthy women as probiotic candidates. Int. Microbiol. 11, 261-266. doi: 10.2436/20.1501.01.70

Miller, E. A., Beasley, D. E., Dunn, R. R., and Archie, E. A. (2016). Lactobacilli dominance and vaginal $\mathrm{pH}$ : why is the human vaginal microbiome unique? Front. Microbiol. 7:1936. doi: 10.3389/fmicb.2016.01936

Mirmonsef, P., Hotton, A. L., Gilbert, D., Burgad, D., Landay, A., Weber, K. M., et al. (2014). Free glycogen in vaginal fluids is associated with Lactobacillus colonization and low vaginal pH. PLoS ONE 9:e102467. doi: 10.1371/journal.pone.0102467

Mirmonsef, P., Hotton, A. L., Gilbert, D., Gioia, C. J., Maric, D., Hope, T. J., et al. (2016). Glycogen levels in undiluted genital fluid and their relationship to vaginal $\mathrm{pH}$, Estrogen, and Progesterone. PLoS ONE 11:e0153553. doi: 10.1371/journal.pone.0153553

Nunn, C. L., Gittleman, J. L., and Antonovics, J. (2000). Promiscuity and the primate immune system. Science 290, 1168-1170. doi: 10.1126/science.290. 5494.1168

Nunn, C. L., Gittleman, J. L., and Antonovics, J. (2003). A comparative study of white blood cell counts and disease risk in carnivores. Proc. R. Soc. B Biol. Sci. 270, 347-356. doi: 10.1098/rspb.2002.2249

Nunn, K. L., and Forney, L. J. (2016). Focus: microbiome: unraveling the dynamics of the human vaginal microbiome. Yale J. Biol. Med. 89:331.
Paavonen, J. (1983). Physiology and ecology of the vagina. Scand. J. Infect. Dis. Suppl. 40, 31-35.

Roccasalva, L. S., Ragonese, S., Tempera, G., and Furneri, P. M. (2002). Vaginal bacterial colonisation in post-menopause: focus on uropathogens. Ital. J. Gynaecol. Obstet. 14, 49-55.

Rosenberg, K., and Trevathan, W. (2002). Birth, obstetrics and human evolution. BJOG 109, 1199-1206. doi: 10.1046/j.1471-0528.2002.00010.x

Shen, J., Song, N., Williams, C. J., Brown, C. J., Yan, Z., Xu, C., et al. (2016). Effects of low dose estrogen therapy on the vaginal microbiomes of women with atrophic vaginitis. Sci. Rep. 6:24380. doi: 10.1038/srep24380

Stumpf, R. M., Wilson, B. A., Rivera, A., Yildirim, S., Yeoman, C. J., Polk, J. D., et al. (2013). The primate vaginal microbiome: comparative context and implications for human health and disease. Am. J. Phys. Anthropol. 152, 119-134. doi: 10.1002/ajpa.22395

Tachedjian, G., Aldunate, M., Bradshaw, C. S., and Cone, R. A. (2017). The role of lactic acid production by probiotic Lactobacillus species in vaginal health. Res. Microbiol. 20, S0923-S2508. doi: 10.1016/j.resmic.2017.04.001

Tempera, G., and Furneri, P. M. (2010). Management of aerobic vaginitis. Gynecol. Obstet. Invest. 70, 244-249. doi: 10.1159/000314013

Thrall, P. H., Antonovics, J., and Bever, J. D. (1997). Sexual transmission of disease and host mating systems: within-season reproductive success. Am. Nat. 149, 485-506.

Thrall, P. H., Antonovics, J., and Dobson, A. P. (2000). Sexually transmitted diseases in polygynous mating systems: prevalence and impact on reproductive success. Proc. R. Soc. Lond. Ser. B Biol. Sci. 267, 1555-1563. doi: $10.1098 / \mathrm{rspb} .2000 .1178$

Vitali, B., Pugliese, C., Biagi, E., Candela, M., Turroni, S., Bellen, G., et al. (2007). Dynamics of vaginal bacterial communities in women developing bacterial vaginosis, candidiasis, or no infection, analyzed by PCR-denaturing gradient gel electrophoresis and real-time PCR. Appl. Environ. Microbiol. 73, 5731-5741. doi: 10.1128/AEM.01251-07

Wagner, G., and Ottesen, B. (1982). Vaginal physiology during menstruation. Ann. Intern. Med. 96, 921-923.

Wylie, J. G., and Henderson, A. (1969). Identity and glycogen-fermenting ability of Lactobacilli isolated from the vagina of pregnant women. J. Med. Microbiol. 2, 363-366, doi: 10.1099/00222615-2-3-363

Conflict of Interest Statement: The authors declare that the research was conducted in the absence of any commercial or financial relationships that could be construed as a potential conflict of interest.

Copyright (c) 2017 Fuochi, Li Volti and Furneri. This is an open-access article distributed under the terms of the Creative Commons Attribution License (CC BY). The use, distribution or reproduction in other forums is permitted, provided the original author(s) or licensor are credited and that the original publication in this journal is cited, in accordance with accepted academic practice. No use, distribution or reproduction is permitted which does not comply with these terms. 